\title{
Het MAB vóór 50 jaar
}

\section{A. F. Tempelaar}

\section{april 1940}

Prof. Th. Limperg Jr. had in het Algemeen Handelsblad van 26 en 27 januari 1940 waarschuwende woorden laten horen betreffende de voorstellen van de Vereeniging voor den Effectenhandel een accountantsonderzoek te laten instellen bij de leden van de vereniging (zie het historisch verslag in het nummer van januari/februari 1990 AFT). Omdat het gestelde probleem ook de functie van de accountant raakt, acht Limperg het gewenst in het MAB nader op het vraagstuk van de 'Accountantscontrole in het Effectenbedrijf' in te gaan. De schrijver kan het billijken dat zijn artikel in het Algemeen Handelsblad bij menigeen onder de accountants bedenkingen zal hebben ontmoet, niet zozeer uit eigen belang, maar gezien het maatschappelijk belang en dat van het vak. Er werd namelijk voorgesteld een accountantscontrole in te voeren in een bedrijfstak waar deze nog maar weinig wordt toegepast; men probeert door die accountantscontrole maatschappelijke euvelen te keren. Maar dan komt nota bene de hoogleraar Limperg een blokkade opwerpen en stelt hij de onmacht van de accountant publiekelijk in het licht.

Toch hebben volgens Limperg die verontruste accountants het bij het verkeerde eind. Zijns inziens schuilt er niets beschamends, veeleer iets lofwaardigs in wanneer de accountants erkennen dat 'het resultaat van hun arbeid beperkt wordt in overeenstemming met de beperkte doeltreffendheid van de hun ten dienste staande controlemiddelen'.

Blijkens de mededelingen van het Bestuur van de Vereeniging voor den Effectenhandel is het doel van de voorstellen het scheppen van waarborgen voor een ordelijk beheer, met name waarborgen tegen de schadelijke gevolgen wangedrag van en misbruik van vertrouwen door leden van de vereniging. Aanleiding was immers de deconfiture van een firma welke eerst kort lid was van de vereniging en het wangedrag en misbruik van vertrouwen door enkele andere leden. Volgens Limperg zal er bij de accountants die het commissionnairsbedrijf uit de praktijk kennen geen meningsverschil bestaan dat een dergelijke waarborg onmogelijk door de accountant kan worden gegeven. Door deze functie te aanvaarden zou de accountant een groter vertrouwen wekken dan hij als vakman gerechtvaardigd mag achten.

Het Bestuur van de Vereeniging voor den Effectenhandel heeft een tweede circulaire het licht doen zien waarbij werd medegedeeld dat leden wier administratie reeds door een lid NIvA of VAGA werd gecontroleerd geen accountantscontrole namens de vereniging behoefden te ondergaan, mits deze leden hun accountant machtigden jaarlijks een verklaring af te geven, waarin antwoord wordt gegeven op de volgende vragen: 1 of er naar het oordeel van de accountant reden is te betwijfelen dat de belangen van de crediteuren van het betrokken lid veilig zijn;

2 of de aan het betrokken lid uit verschillenden hoofde toevertrouwde waarden behoorlijk worden beheerd.

Ook dit amendement op het oorspronkelijke voorstel wordt door Limperg categorisch afgewezen.

De schrijver ziet wel waarde in een accountantscontrole welke wordt verricht uitsluitend ten behoeve van de eigenaar van het commissionnairshuis en van de kleine kring van medebelanghebbenden die zich bewust zijn van het bestaan

A. F. Tempelaar, registeraccountant, was lid van de maatschap Dijker en Doornbos (rechtsvoorganger van Deloitte Dijker Van Dien) en vervulde vele functies in de beroepsorganisaties in binnen- en buitenland. 


\section{MAB}

van de door Limperg aangegeven zwakke stee in de controle en die derhalve het daarin vervatte risico bewust aanvaarden.

De verklaring van de accountant reikt dan niet verder dan de aangegeven kleine kring. Een dergelijke opdracht verschilt wezenlijk van die welke het Bestuur van de vereniging voor ogen had, want daar wordt een publieke verklaring vereist, aldus Limperg. (Was het R.A. Dijker niet die destijds een lans brak voor het onderscheid in publieke en private taak? - AFT.)

Ook ziet Limperg wel een mogelijkheid voor een accountant in dienst van de vereniging. Die wekt geen groter vertrouwen dan de vervulling van zijn functie met beperkte doelstelling toelaat. Wel moet de vereniging dan duidelijk maken dat het niet gaat om het scheppen van waarborg van soliditeit en solvabiliteit, maar alleen om de verzorging van een goede methode van administratie en beheer der toevertrouwde waarden.

In hetzelfde nummer reageert H. H. M. Foppe die het hierboven besproken artikel van Limperg nog niet heeft gelezen - op het in de maand februari 1940 gepubliceerde artikel van de hooggeleerde. Foppe is het met de conclusie van Limperg eens, maar wil van de schrijver weten of de onmogelijkheid een publieke verklaring af te geven in het effectenbedrijf een gevolg is van de aard van het bedrijf (waar vermogensvergrijpen door bestuurders mogelijk zijn) of het gevolg is van de geringe grootte (met onvoldoende functiescheiding). In zijn naschrift stelt Limperg, dat zelfs in grote commissiehuizen het verkeer met de cliënten, wat de waarden betreft voor een groot deel beperkt is tot de eigenaren van het bedrijf. Indien de controlemogelijkheden bij grotere bedrijfseenheden wel mogelijk zouden worden, zou volgens Foppe er naar moeten worden gestreefd het bedrijf van banken en het effectenbedrijf samen te trekken. Limperg wijst er op dat de door de vereniging voorgestelde maatregelen in feite tot doel hadden het commissionnairsbedrijf tegen de concurrentie van het grootbankbedrijf te beschermen.

Aan het einde van dit nummer volgt nog de volledige weergave van de Memorie van Antwoord betreffende het ontwerp van wet tot vaststelling van regelen betreffende het accountantswezen, ondertekend door Minister Steenberghe. De Minister houdt staande dat de regering alleen regelen wil geven om het publieke belang te dienen, dat is alleen daar waar hoge eisen aan de kennis en de onafhankelijkheid van accountants worden gesteld. Voor bedieners die zich voornamelijk met kleine ondernemingen bezighouden, ziet hij geen publiek belang om te regelen.

Op verzoek van de Kamer zijn enkele overzichten aan de memorie toegevoegd.

Uit historisch oogpunt zijn de volgende gegevens interessant:

(Volgens de Minister bestaat er ook nog een Nederlandsche Federatie van Accountants, maar hieromtrent staan hem geen gegevens ter beschikking zie schema.) 


\section{MAB}

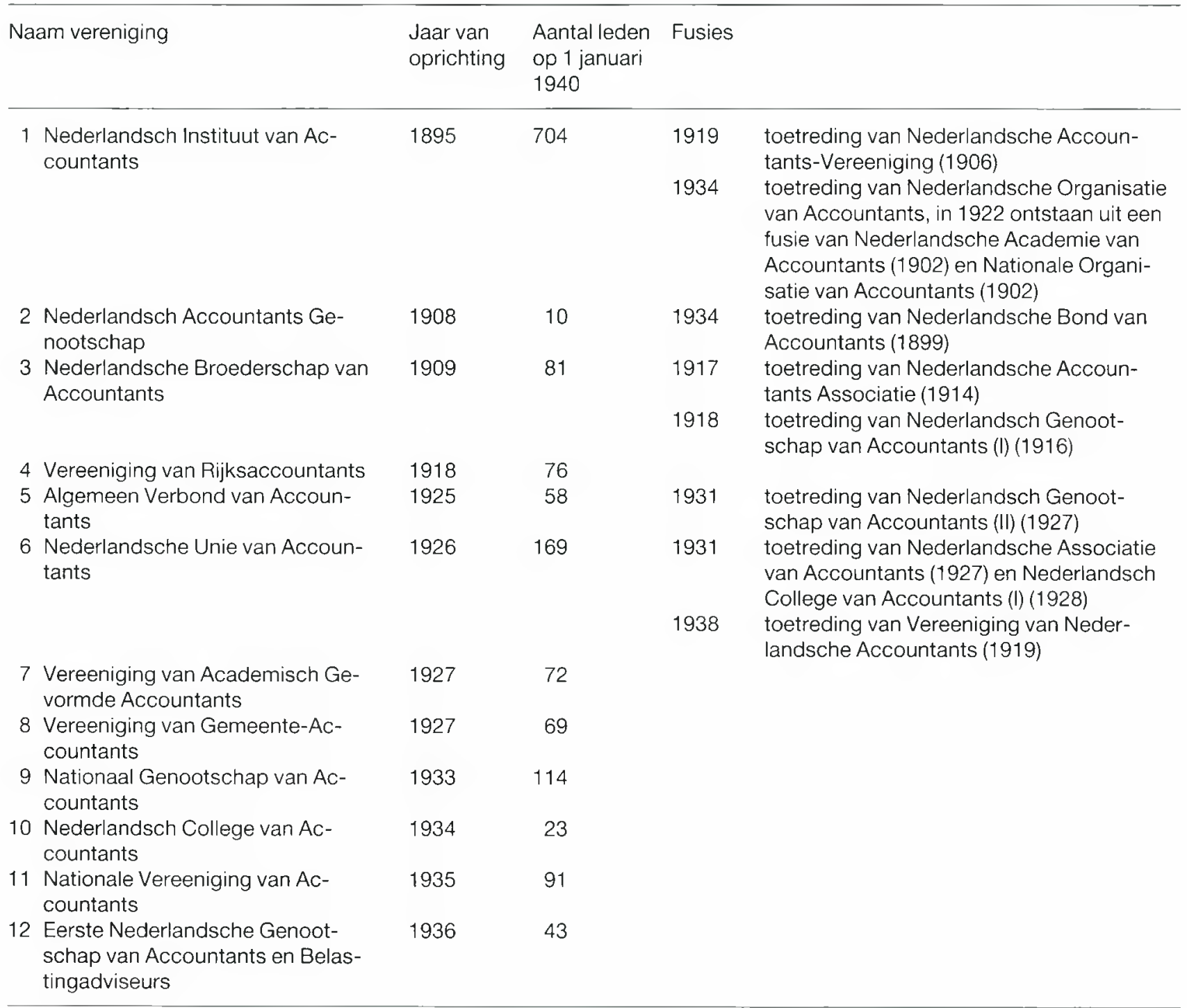

